\title{
A Comparative Study of Water Quality Between Hot Spring and Borehole Waters of Mara, Shinyanga and Manyara Regions of Tanzania
}

\author{
Samwel Alfred Maseke, Maheswara Rao Vegi* \\ The Department of Chemistry, The University of Dodoma, Dodoma, Tanzania \\ Email address: \\ sindamaseke40@gmail.com (S. A. Maseke), vegimahesh@gmail.com (M. R. Vegi) \\ ${ }^{*}$ Corresponding author
}

\section{To cite this article:}

Samwel Alfred Maseke, Maheswara Rao Vegi. A Comparative Study of Water Quality Between Hot Spring and Borehole Waters of Mara, Shinyanga and Manyara Regions of Tanzania. Science Journal of Chemistry. Vol. 7, No. 4, 2019, pp. 82-89. doi: 10.11648/j.sjc.20190704.13

Received: September 25, 2019; Accepted: October 11, 2019; Published: October 23, 2019

\begin{abstract}
This study conducted for the comparison of physico-chemical parameters between hot springs and borehole waters. Fourteen samples were collected at Mara, Shinyanga and Manyara in Tanzania. Multimeter used for the analysis of physical parameters $\mathrm{pH}, \mathrm{EC}$, TDS, salinity and turbidity. Titrimetric methods were used for the determination of $\mathrm{Cl}^{-}$, total hardness, $\mathrm{Ca}^{2+}$ and $\mathrm{Mg}^{2+}$. UV-Vis. Spectrophotometric method for $\mathrm{NO}_{3}{ }^{-}, \mathrm{SO}_{4}{ }^{2-}, \mathrm{F}^{-}, \mathrm{Fe}^{2+}$ and $\mathrm{Mn}^{2+}$ and Flame Atomic Absorption Spectrometer for $\mathrm{Cd}^{2+}, \mathrm{Zn}^{2+}, \mathrm{Ni}^{2+}, \mathrm{Cu}^{2+}$ and $\mathrm{K}^{+}$. The EC, TDS, salinity, turbidity, $\mathrm{Cl}^{-}, \mathrm{NO}_{3}^{-}, \mathrm{SO}_{4}^{2-}, \mathrm{F}^{-}, \mathrm{Mn}^{2+}$ and $\mathrm{Cu}^{2+}$ are higher $\left(\mathrm{pH}=7.44-9.42, \mathrm{EC}=4251.33-15334 \mu \mathrm{S} / \mathrm{cm}, \mathrm{TDS}=2079-7526.7 \mathrm{mg} / \mathrm{L}\right.$, salinity $=2.2-8.67 \mathrm{ppt}, \mathrm{Cl}^{-}=189.3-$ $3577.6 \mathrm{mg} / \mathrm{L}, \mathrm{SO}_{4}{ }^{2-}=11.83-1353.33 \mathrm{mg} / \mathrm{L}, \mathrm{F}^{-}=4.68-18 \mathrm{mg} / \mathrm{L}, \mathrm{Mn}^{2+}=1.03-2.0 \mathrm{mg} / \mathrm{L}, \mathrm{Cd}^{2+}=0.01-0.05 \mathrm{mg} / \mathrm{L}, \mathrm{Cu}^{2+}=0.37-$ $0.93 \mathrm{mg} / \mathrm{L}$ and $\left.\mathrm{K}^{+}=44-100 \mathrm{mg} / \mathrm{L}\right)$ in hot springs than borehole waters $(\mathrm{pH}=6.36-6.58, \mathrm{EC}=270.0-2674.64 \mu \mathrm{S} / \mathrm{cm}, \mathrm{TDS}=$ $123.67-1305 \mathrm{mg} / \mathrm{L}$, salinity $=0.03-1.37 \mathrm{ppt}, \mathrm{Cl}^{-}=6.25-659.93 \mathrm{mg} / \mathrm{L}, \mathrm{SO}_{4}{ }^{2-}=28.92-493.33 \mathrm{mg} / \mathrm{L}, \mathrm{F}^{-}=0.89-3.0 \mathrm{mg} / \mathrm{L}, \mathrm{Mn}^{2+}=$ $0.3-1.70 \mathrm{mg} / \mathrm{L} \mathrm{Cd}{ }^{2+}=0 \mathrm{mg} / \mathrm{L}, \mathrm{Cu}^{2+}=0.49-0.64 \mathrm{mg} / \mathrm{L}$ and $\mathrm{K}^{+}=16-52 \mathrm{mg} / \mathrm{L}$ ). The t-test at the probability 0.05 showed that there is significant difference of the parameters $\mathrm{pH}$ and $\mathrm{Ni}^{2+}$ between hot spring and borehole waters. Some of the parameters are at higher levels than permissible values for both hot spring and borehole waters. Therefore, there is a need of treatment for these waters before using for domestic purpose.
\end{abstract}

Keywords: Hot Spring Water, Borehole Water, Physico-chemical Parameters, Titrimetry, Spectrophotometry, FAAS

\section{Introduction}

Water is a transparent and nearly colorless substance which is the main constituents of earth and fluids of most living organisms. Earth's surface water moves continuously through the water cycles. Okoro, et al., (2017) identified that the large amounts of water are chemically combined or adsorbed in hydrated minerals [1].

Groundwater is naturally recharged by rain water and snow melt or from water that leaks through the bottom of some lakes and rivers [2]. This water stored in the layers beneath the surface and helps protecting from contamination from its quality. However the temporal and spatial distribution of both surface and groundwater sources were not uniform and is controlled by climate and geology [3]. Therefore, water from underground contained $95 \%$ of the ions such as $\mathrm{Na}^{+}, \mathrm{K}^{+}, \mathrm{Mg}^{2+}, \mathrm{Ca}^{2+}, \mathrm{Cl}^{-}, \mathrm{SO}_{4}^{2-}$ and $\mathrm{F}^{-}$.

Water recharged and percolates deeply enough into the crust and heated as it comes into contact with hot rocks [4]. That influences the soluble mineral contents in hot waters and varies widely in their mineral composition of the local area. Kifua, (1958) identified more than 15 hot springs with above $40^{\circ} \mathrm{C}$ found over and near the active rift segments in Tanzania [5]. Locations of hot springs are usually depending on the East African rift valley that indicates geothermal activity [6]. The hot springs found in Mara, Shinyanga and Manyara are located at the swamp areas and bedrock surfaces. Borehole water is constructed by a narrow shaft bored in the ground vertically for the extraction of water [7]. Most of these boreholes support many people of urban, rural and remote areas around Tanzania.

The major source of groundwater in Mara and Shinyanga 
regions are from the Lake Victoria basin, but in Manyara it is internal drainage basin. Water quality assessment in different water sources is very important in order to know the levels of natural and human induced contaminants for public and ecosystem health management interests. Therefore, hot springs being a part of water source in order to solve the water scarcity in the areas Majimoto, Uzogore, Masware and Lalaji, this study conducted to compare the physico-chemical parameters of hot spring water with that of borehole and permissible levels of drinking water from Tanzania Bureau of Standard (TBS) and World Health Organization (WHO). The parameters which help to define water quality includes: turbidity, EC, $\mathrm{pH}, \mathrm{TDS}$, total hardness and anions such as $\mathrm{Cl}^{-}$, $\mathrm{SO}_{4}{ }^{2-}, \mathrm{F}^{-}, \mathrm{NO}_{3}{ }^{-}$and others cations $\mathrm{K}^{+}, \mathrm{Ca}^{2+}$ and $\mathrm{Mg}^{2+}$.

\section{Materials and Methods}

\subsection{Study Area}

The selected regions of this study comprised Mara, Shinyanga and Manyara as shown in Figure 1, Mara region $\left(1^{\circ} 45^{\prime} 00^{\prime \prime} \mathrm{S}\right.$ and $\left.34^{\circ} 00^{\prime} 00^{\prime \prime} \mathrm{E}\right)$ in which Serengeti district with one hot spring site called Majimoto. Shinyanga region $\left(3^{\circ} 45^{\prime} 00^{\prime \prime} \mathrm{S}\right.$ and $\left.33^{\circ} 00^{\prime} 00^{\prime \prime} \mathrm{E}\right)$ in which Shinyanga town contained one hot spring site known as Usangore/Uzogore. In Manyara region $\left(4^{\circ} 45^{\prime} 00^{\prime \prime} \mathrm{S}\right.$ and $\left.36^{\circ} 40^{\prime} 00^{\prime \prime} \mathrm{E}\right)$ there were two hot springs for the study that found in two districts Babati and Hanang'i namely Masware and Balangida, respectively. Borehole waters were found in the community with approximate distance of $0.5 \mathrm{~km}$ from hot spring sites.

\subsection{Sample Collection and Storage}

Before collection of the water samples a container of volume $1 \mathrm{~L}$ was cleaned through washing with distilled water three to four times and rinsed with water sample in order to avoid contamination [8]. Two kinds of water samples, hot springs and borehole waters were collected. A total of 7 sites for water sample collected with two sets of water samples to each site. A total of fourteen samples were collected, whereby seven samples for physical and some chemical parameters and other seven used for FAAS analysis. Water samples from hot springs as well as borehole waters collected periodically for every 20 minutes for 1 hour with a volume of $900 \mathrm{~mL}$ from each sample.

After collection in each study site all samples were labeled as observed in Table 1 with specific descriptions mainly name and code of the sample then sealed to protect from atmospheric reactions. Water samples were transported by maintaining temperature at $4^{\circ} \mathrm{C}$ with a thermos cool box. Water samples collected for the analysis of heavy metals were prepared separately by treating with $2 \mathrm{~mL}$ of $\mathrm{HNO}_{3}$ for $1 \mathrm{~L}$ of water sample in order to prevent adsorption on the walls of the container. Water samples transported to Dodoma Urban Water Supply and Sewerage Authority (DUWASA), Mwanza Zonal Water Quality (MZWQ) and Geological Survey of Tanzania (GST) laboratories for further analysis.

Table 1. Coding and labeling of water samples collected in the study.

\begin{tabular}{ll}
\hline Water sampling sites & Code/Label \\
\hline Hot spring sampling at Majimoto - Mara & $\mathrm{HSW}_{1}$ \\
Hot spring sampling at Usangore - Shinyanga & $\mathrm{HSW}_{2}$ \\
Hot spring sampling at Masware - Manyara & $\mathrm{HSW}_{3}$ \\
Hot spring sampling at Lalaji (Balangida Lalu) - Manyara & $\mathrm{HSW}_{4}$ \\
Borehole water sampling at Majimoto - Mara & $\mathrm{BHW}_{1}$ \\
Borehole water sampling at Uzogore - Shinyanga & $\mathrm{BHW}_{2}$ \\
Borehole water sampling at Masware - Manyara & $\mathrm{BHW}_{3}$ \\
\hline
\end{tabular}

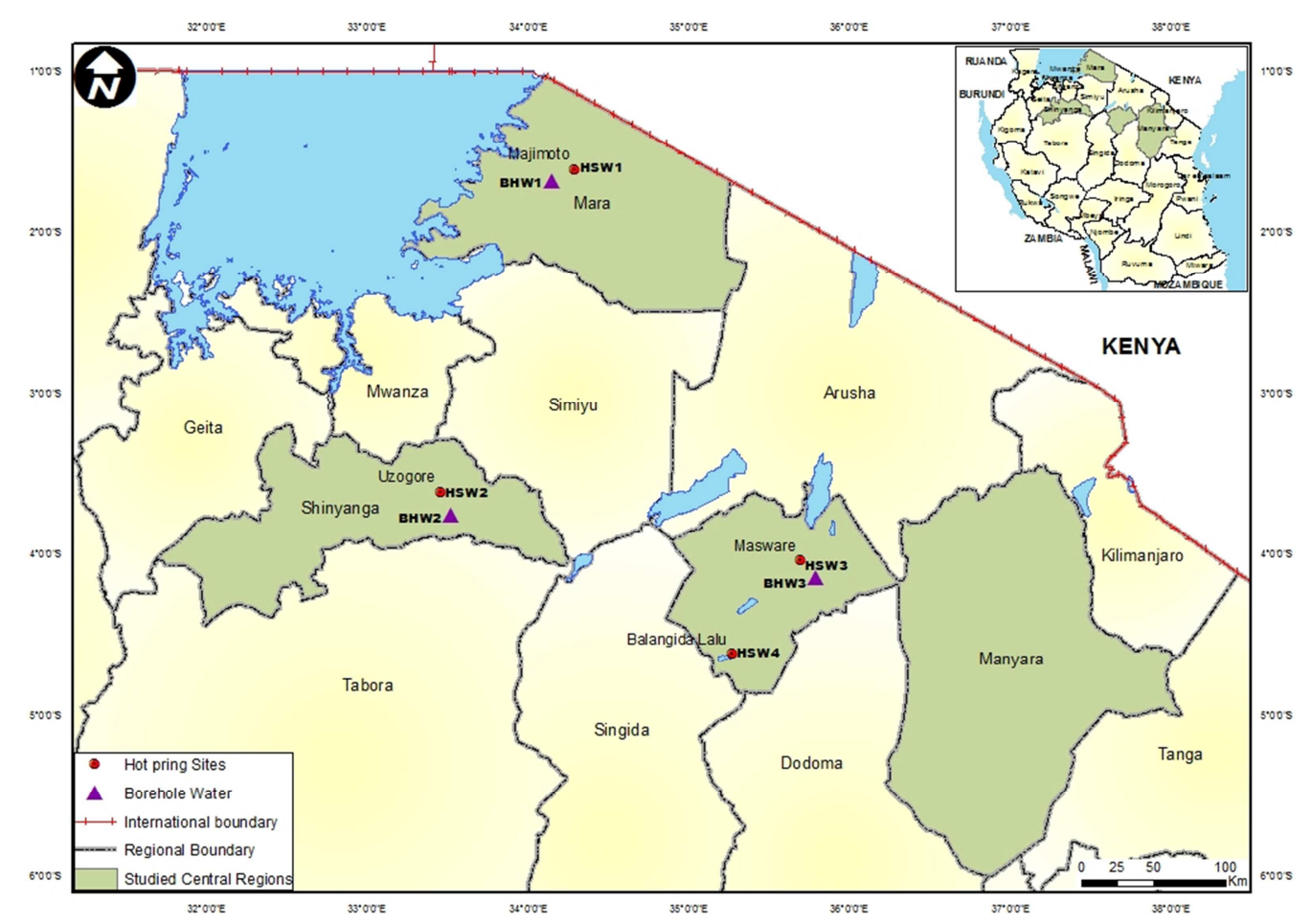

Figure 1. Tanzania map showing the selected hot spring sites and borehole waters with their respective regions. 


\subsection{Water Sample Analysis}

Four methods were used to analyze nineteen physicochemical parameters in each sample. Before analysis the instruments were calibrated with standard solutions prepared based on the respective ions or parameter analysed in order to get accuracy and precision of the respective instruments. All the chemicals used in this study were analytical grade from the manufacturer Sigma Aldrich, Germany. Buffer solutions for $\mathrm{pH}$ 's 4, 7 and 10, EC standard solutions 1.5, 147 and 1413 $\mu \mathrm{S} / \mathrm{cm}$ used to calibrate $\mathrm{pH}$ meter and multimeter for analyzing $\mathrm{pH}, \mathrm{EC}, \mathrm{TDS}$ and salinity. $\mathrm{Cl}^{-}$analyzed by titrating with $\mathrm{AgNO}_{3}$ using $\mathrm{K}_{2} \mathrm{CrO}_{4}$ as an indicator. Buffer solution $\left(\mathrm{NH}_{4} \mathrm{Cl}+\mathrm{NH}_{4} \mathrm{OH}\right)$ and $\mathrm{NaOH}$ solution used to raise the $\mathrm{pH}$ in the determination of total hardness and $\mathrm{Ca}^{2+}$, respectively. Disodium salt of EDTA $(0.01 \mathrm{M})$ was used to determine the total hardness and $\mathrm{Ca}^{2+}$ with EBT and Ammonium purpurate as indicators.

UV-Vis spectrophotometry was used to analyze some of the ions present in water samples using respective powder pillows. NitraVer 5 nitrate pillow was used for the analysis of $\mathrm{NO}_{3}{ }^{-}$at $\lambda_{\max } 500 \mathrm{~nm}$. SulfaVer 4 sulphate pillows were used to analyse $\mathrm{SO}_{4}{ }^{2-}$ at $\lambda_{\max } 450 \mathrm{~nm}$. SPADNS reagent used to analyse $\mathrm{F}^{-}$at $\lambda_{\max } 580 \mathrm{~nm}$. FerroVer Iron pillows were used for the analysis of $\mathrm{Fe}^{2+}$ at $\lambda_{\max } 510 \mathrm{~nm}$. Buffer powder citrate pillows with sodium periodate pillows were used to analyze $\mathrm{Mn}^{2+}$ at $\lambda_{\max } 525 \mathrm{~nm}$.

FAAS and acetylene-air were used for the analysis of heavy metals with acidified water samples for the analysis of metals $\mathrm{Cd}^{2+}, \mathrm{Zn}^{2+}, \mathrm{Ni}^{2+}, \mathrm{Cu}^{2+}$ and $\mathrm{K}^{+}$in water samples with respective wavelength $228.8 \mathrm{~nm}, 213.9 \mathrm{~nm}, 232 \mathrm{~nm}, 324.7$ $\mathrm{nm}$ and $766.5 \mathrm{~nm}$.

\subsection{Data Analysis}

Sample collection, handling, preservation and analyses were done by following standard procedures recommended by the American Public Health Association which ensure data quality and consistency. For every measurement, triplicate readings recorded and mean values presented with their standard deviations. Numerical data obtained from experimental work were analyzed by t-test and ANOVA using Microsoft Excel 2007. The numerical data of physicochemical parameters obtained in this study were compared with the standard values of Tanzania Bureau of Tanzania (TBS) and WHO.

\section{Results and Discussion}

\subsection{Temperatures of Hot Spring Water Samples}

In Manyara region two hot springs were analyzed which are Balangida Lalu and Masware. Balangida Lalu hot spring water drained, gathered and formed as ponds at large swamp area. Its temperature ranged $33-36^{\circ} \mathrm{C}$. Masware hot springs are divided into two faults associated with small swamps and its temperature ranged $41-48^{\circ} \mathrm{C}$. One hot spring found in each of Mara and Shinyanga regions with the site names Majimoto and Usangore, respectively contained high temperatures that range between 58 and $67^{\circ} \mathrm{C}$. Animals and human use hot water directly from spring sources for drinking and bathing.

The significance of temperature is the identification of distances between rocks in the earth crust. Groundwater temperature increases with depth which in turn increase dissolved minerals and silicates with mud pot [9]. The measure of temperature helped to identify existence of hot springs in the study areas which distinguishes from borehole water.

\section{2. pH, EC, TDS, Salinity and Turbidity}

The ranges of $\mathrm{pH}, \mathrm{EC}$, TDS, salinity and turbidity are 6.36-9.34, 270-15334 $\mu \mathrm{S} / \mathrm{cm}, 123.67-7526.7 \mathrm{mg} / \mathrm{L}, 0.03-8.67$ ppt and 0.55-26.23 NTU, respectively (Table 2). Higher $\mathrm{pH}$ of 9.42 recorded in Balangida Lalu $\left(\mathrm{HSW}_{4}\right)$ hot spring water. Permissible levels of $\mathrm{pH}$ in drinking water are 6.5-9.2 and 6.5-8.5 according to the guidelines of TBS and WHO, respectively. Toure, et al., (2017) identified higher $\mathrm{pH}$ values in hot spring compared with the borehole water due to the presence of the high levels of $\mathrm{HCO}_{3}{ }^{-}$or $\mathrm{CO}_{3}{ }^{2-}$ and $\mathrm{OH}^{-}$which causes the alkalinity in water [10]. The t-test shows that there are significant differences in $\mathrm{pH}$ values between hot spring and borehole water with $\mathrm{p}$-value less than $0.05(0.016<$ $0.05)$.

The values of EC, TDS and salinity found higher in Balangida Lalu $\left(\mathrm{HSW}_{4}\right)$ hot spring with $15334 \mu \mathrm{S} / \mathrm{cm}$, $7526.7 \mathrm{mg} / \mathrm{L}$ and $8.67 \mathrm{ppt}$, respectively. Lower values found in Masware hot spring $\left(\mathrm{HSW}_{3}\right)$ than other hot springs Majimoto $\left(\mathrm{HSW}_{1}\right)$ and Usangore $\left(\mathrm{HSW}_{2}\right)$. EC, TDS and salinity values were less in boreholes waters compared to that of hot springs. The increase in the values of EC leads to increase in the TDS and salinity values as it is reflected in the data (Table 2). The ions responsible for EC of water come from dissolved salts and inorganic materials such as alkalis, chlorides, sulphides and carbonate compounds [11]. Dissolution of ions generally occurs in the groundwater by rapid ion-exchange between the soil and water. Instead of soil if there is a rock with insoluble minerals then that leads to low EC of water. The variation in the values of salinity caused by rock weathering that allows salt to be released as minerals break down over time as well as raise of water tables [12]. Permissible level of EC in drinking water is 2500 according to WHO. Permissible levels of TDS according to guideline of TBS ranges between $500-1200 \mathrm{mg} / \mathrm{L}$ and that of WHO is $1000 \mathrm{mg} / \mathrm{L}$. All the hot spring water under study and one borehole water (Masware, $\mathrm{BHW}_{3}$ ) have higher values of EC and TDS than permissible levels of drinking water. In the $\mathrm{t}$-test, the obtained $\mathrm{p}$-values were greater than 0.05 , ( $\mathrm{p}$ for EC $=0.06, \mathrm{p}$ for TDS $=0.074$ and $\mathrm{p}$ for salinity $=0.083)$ which is proving that there are no significant differences of EC, TDS and salinity between hot springs and borehole waters. Turbidity values ranged between 0.4 and 26.23 NTU. The permissible levels are ranged 5-25. All the water samples 
having turbidity values with in the guideline values except Majimoto borehole water (BHW1).

Table 2. Physical parameters analysed by multimeters.

\begin{tabular}{|c|c|c|c|c|c|c|c|c|c|c|c|c|c|c|c|}
\hline \multirow{3}{*}{ Samples } & \multicolumn{3}{|l|}{ pH } & \multicolumn{3}{|l|}{ EC } & \multicolumn{3}{|l|}{ TDS } & \multicolumn{3}{|c|}{ Salinity } & \multicolumn{3}{|c|}{ Turbidity } \\
\hline & & SD & $\%$ & Mean & SD & $\%$ & Mean & SD & $\%$ & Mean & SD & $\%$ & Mean & SD & $\%$ \\
\hline & Mean & $(n=3)$ & RSD & $(\mu \mathrm{S} / \mathrm{cm})$ & $(n=3)$ & RSD & $(\mathrm{mg} / \mathrm{L})$ & $(n=3)$ & RSD & (ppt) & $(n=3)$ & RSD & (NTU) & $(n=3)$ & RSD \\
\hline $\mathrm{HSW}_{1}$ & 9.07 & 0.06 & 0.71 & 9523.67 & 7.23 & 0.07 & 4233.7 & 9.07 & 0.21 & 4.57 & 0.15 & 3.35 & 0.4 & 0.04 & 9.01 \\
\hline $\mathrm{HSW}_{2}$ & 8.53 & 0.03 & 0.31 & 5740.33 & 1.53 & 0.03 & 2583.7 & 4.51 & 0.18 & 2.6 & 0.2 & 7.69 & 2.29 & 0.02 & 0.67 \\
\hline $\mathrm{HSW}_{3}$ & 7.44 & 0.04 & 0.49 & 4251.33 & 5.13 & 0.12 & 2079 & 9.85 & 0.47 & 2.2 & 0.2 & 9.09 & 4.11 & 0.02 & 0.49 \\
\hline $\mathrm{HSW}_{4}$ & 9.42 & 0.03 & 0.27 & 15334 & 30.3 & 0.2 & 7526.7 & 4.51 & 0.06 & 8.67 & 0.15 & 1.76 & 5.43 & 0.25 & 4.63 \\
\hline $\mathrm{BHW}_{1}$ & 6.44 & 0.1 & 1.53 & 270 & 3 & 1.11 & 123.67 & 2.08 & 1.68 & 0.03 & 0.06 & 173.2 & 26.23 & 0.31 & 1.17 \\
\hline $\mathrm{BHW}_{3}$ & 6.36 & 0.22 & 3.42 & 2674.67 & 4.51 & 0.17 & 1305 & 13.08 & 1 & 1.37 & 0.15 & 11.18 & 0.55 & 0.01 & 1.82 \\
\hline TBS & $6.5-9.2$ & & & - & & & $500-1200$ & & & - & & & 5 to 25 & & \\
\hline WHO & $6.5-8.5$ & & & 2500 & & & 1000 & & & - & & & 5 to 25 & & \\
\hline
\end{tabular}

\subsection{Chlorides}

The concentrations of $\mathrm{Cl}^{-}$in hot spring ranges from 189.30 to $3577.6 \mathrm{mg} / \mathrm{L}$ while in borehole water it is from 6.25 to $659.93 \mathrm{mg} / \mathrm{L}$ (Table 3). Chloride ions leached from various rocks into both hot spring and borehole waters by weathering and transported to closed basin because of high mobility of chlorides [13]. Permissible levels of $\mathrm{Cl}^{-}$in drinking water according to TBS and WHO drinking water guideline are 200 to $800 \mathrm{mg} / \mathrm{L}$ and 200 to $600 \mathrm{mg} / \mathrm{L}$ respectively. From the data obtained, it is observed that there are high levels of $\mathrm{Cl}^{-}$in hot spring water compared to permissible levels as well as values of borehole waters. High levels of $\mathrm{Cl}^{-}$in hot spring water give objectionable taste. There is no significant difference of chloride concentrations between hot spring and borehole waters from the t-test with $\mathrm{p}$-values 0.35 which is greater than 0.05 .

\subsection{Total Hardness, Calcium and Magnesium}

The values of total hardness, $\mathrm{Ca}^{2+}$ and $\mathrm{Mg}^{2+}$ in all the sites under this study are shown in Table 3. Total hardness increases the concentration of $\mathrm{Ca}^{2+}$ and $\mathrm{Mg}^{2+}$ and also $\mathrm{Ca}^{2+}$ is more abundant than $\mathrm{Mg}^{2+}$. Total hardness ranges from 1.59$435.98 \mathrm{mg} / \mathrm{L}$ for hot spring and 22.08-430.4 mg/L for borehole waters. $\mathrm{Ca}^{2+}$ values ranges $0.26-103.9 \mathrm{mg} / \mathrm{L}$ in hot spring and $5.77-51.28 \mathrm{mg} / \mathrm{L}$ in borehole waters. It is observed that more concentrations in $\mathrm{Ca}^{2+}$ in borehole than hot spring water except for the site Masware $\left(\mathrm{HSW}_{3}\right)$. The concentration of $\mathrm{Mg}^{2+}$ ranges $0.24-42.92 \mathrm{mg} / \mathrm{L}$ in hot springs and 1.1173.49 in borehole waters. $\mathrm{Ca}^{2+}$ and $\mathrm{Mg}^{2+}$ are responsible for hardness in water. Their presence is the result of dissolution of these salts when the flowing water comes in contact with rock of carbonate minerals such as calcite and dolomite [14]. Permissible levels of hardness are from $500-600 \mathrm{mg} / \mathrm{L}$ and $300 \mathrm{mg} / \mathrm{L}$ according to TBS and WHO respectively. Obtained values in this study are less than the maximum permissible level set by TBS where as both hot spring and borehole waters of Masware $\left(\mathrm{HSW}_{3}\right.$ and $\mathrm{BHW}_{3}$ ) sites have higher values than the maximum permissible levels set by WHO. There is no significant difference in total hardness, $\mathrm{Ca}^{2+}$ and $\mathrm{Mg}^{2+}$ between hot springs and borehole waters from t-test with p-values of $0.50,0.85$ and 0.29 , respectively. In all the cases p-value obtained is greater than 0.05 .

\subsection{Nitrate, Sulphate and Flouride}

Borehole waters have higher concentration of $\mathrm{NO}_{3}{ }^{-}$which ranges from 4.06-39.25 mg/L than hot spring waters (Table 4). This is due to anthropogenic activities conducted near water sources. All hot springs contains lower $\mathrm{NO}_{3}^{-}$ concentration. Commonly $\mathrm{NO}_{3}^{-}$exists in the form of nitrogenous compound in natural processes of the nitrogen cycle. In addition to natural process anthropogenic sources have great influence on the nitrate concentration, particularly in groundwater [15]. The toxicity of nitrate to humans is mainly attributed to its reduction to nitrite. Major biological effect of nitrite in humans is in the oxidation of normal hemoglobin to methaemoglobin which is more susceptible to young infants [16]. The guideline values of nitrate according to TBS and WHO are $10-75$ and $45-50 \mathrm{mg} / \mathrm{L}$ respectively. The nitrate concentration found in this study is within permissible levels. There is no significant difference in $\mathrm{NO}_{3}{ }^{-}$ concentration between hot spring and borehole waters according to t-test $(\mathrm{p}=0.28>0.05)$.

The concentrations of $\mathrm{SO}_{4}{ }^{2-}$ ranged from 11.83-1353.3 $\mathrm{mg} / \mathrm{L}$ for hot spring waters and $28.92-493.33 \mathrm{mg} / \mathrm{L}$ for borehole waters (Table 4). Lower concentrations of $\mathrm{SO}_{4}{ }^{2-}$ found in Usangore hot spring $\left(\mathrm{HSW}_{2}\right)$ with a value of 11.83 $\mathrm{mg} / \mathrm{L}$ and Majimoto borehole $\left(\mathrm{BHW}_{1}\right)$ with a value of 28.92 $\mathrm{mg} / \mathrm{L}$ respectively. The presence of $\mathrm{SO}_{4}{ }^{2-}$ in water mainly caused by groundwater temperature accompanied with nature of rocks from same geologic forces. Sulphates are a part of naturally occurring minerals in some soil and rock formations that contain groundwater [17]. Within the waters many other reactions occur and these typically involve sulphur and/or metal cations. Geothermal waters generally contain sulphur, initially in the form of hydrogen sulphide that may be oxidized, especially in the path of rising to the surface through rock fractures rather than faults [18]. The lowest taste threshold concentration for sulphate is approximately 200 to $400 \mathrm{mg} / \mathrm{L}$ from guideline of WHO and $200-600 \mathrm{mg} / \mathrm{L}$ from the guideline of TBS. All the values obtained in this study are less than the maximum permissible set by TBS except for the site Balangida Lalu $\left(\mathrm{HSW}_{4}\right)$. All the hot spring sites except Usangore $\left(\mathrm{HSW}_{2}\right)$ and one borehole site Masware $\left(\mathrm{BHW}_{3}\right)$ have higher concentrations of sulphate 
than the maximum permissible level set by WHO. In t-test $\mathrm{p}$ $=0.39>0.05$, it is interpreted that there is no significant difference between the $\mathrm{SO}_{4}{ }^{2-}$ concentrations in hot springs and borehole waters.

Hot spring sources showed higher prevalence of $\mathrm{F}^{-}$as compared to borehole waters (Table 4). Very high $\mathrm{F}^{-}$ concentrations of $18,10.5,9.3 \mathrm{mg} / \mathrm{L}$ was found in hot springs of Usangore $\left(\mathrm{HSW}_{2}\right)$, Majimoto $\left(\mathrm{HSW}_{1}\right)$ and Balangida Lalu $\left(\mathrm{HSW}_{4}\right)$, respectively. Among borehole waters maximum concentration of $\mathrm{F}^{-}(3 \mathrm{mg} / \mathrm{L})$ found in Uzogore $\left(\mathrm{BHW}_{2}\right)$. High levels of $\mathrm{F}^{-}$is due to solubilizing more fluoride salts because of the high temperature of hot spring waters compared to borehole water [19]. Fluorides are mainly found in groundwater resulting from the reaction of water with rocks and the soil of the earth crust as well as geothermal activity [20]. In most of the areas with hot spring sites, the water used for drinking purpose by cattle, goats and sheep and found affected with $\mathrm{F}^{-}$concentration levels [21]. Some of the hot springs and all boreholes waters used for domestic purposes directly without any treatment. Usage of fluoride containing water leads to fluorosis to the people. There is an evidence of dental fluorosis for the people in Posht-e-kooh-e-Dashtesan area in southern Iranian communities that reported drinking spring water with more than $3 \mathrm{mg} / \mathrm{L}$ fluoride [22]. Therefore, from this study it is recommended to use these waters after treatment. A majority of the report's authoring committees also concluded that people who drink water containing $4 \mathrm{mg} / \mathrm{L}$ or more of fluoride over a lifetime are likely at increased risk for bone fractures [23]. The permissible guidelines values for fluoride in drinking water from TBS range 1.5 to $4 \mathrm{mg} / \mathrm{L}$, but from WHO it is $1.5 \mathrm{mg} / \mathrm{L}$. Most of the waters studied in this work have their fluoride contents more than the recommended values. The t-test revealed that there is no significant difference between $\mathrm{F}^{-}$in hot springs and borehole waters in which p-value obtained is $0.06>0.05$.

\subsection{Iron and Manganese}

The maximum value of $\mathrm{Fe}^{2+}$ concentrations found at
Usangore $\left(\mathrm{HSW}_{2}\right)$ hot spring with $0.41 \mathrm{mg} / \mathrm{L}$ and Majimoto borehole with $1.22 \mathrm{mg} / \mathrm{L}$ (Table 4). Minimum concentrations of $\mathrm{Fe}^{2+}$ present in Majimoto $\left(\mathrm{HSW}_{1}\right)$ hot spring with 0.003 $\mathrm{mg} / \mathrm{L}$ and Masware $\left(\mathrm{BHW}_{3}\right)$ borehole water with $0.02 \mathrm{mg} / \mathrm{L}$. Permissible levels of $\mathrm{Fe}^{2+}$ in drinking water based on the guideline of TBS and WHO ranged 0.3-1.0 and 0.1-1.0 mg/L, respectively. Values obtained for both hot spring and borehole waters in this study are less than the guideline values except Majimoto borehole water $\left(\mathrm{BHW}_{1}\right)$ indicating that there is no harm in consuming this water with respect to $\mathrm{Fe}^{2+}$.

The higher concentrations of $\mathrm{Mn}^{2+}$ found in Majimoto $\left(\mathrm{HSW}_{1}\right)$ hot spring with $2.00 \mathrm{mg} / \mathrm{L}$ (Table 4). Lowest $\mathrm{Mn}^{2+}$ concentration found at Balangida Lalu $\left(\mathrm{HSW}_{4}\right)$ hot spring water with $1.03 \mathrm{mg} / \mathrm{L}$. Among the borehole waters Uzogore $\left(\mathrm{BHW}_{2}\right)$ and Masware $\left(\mathrm{BHW}_{3}\right)$ water having maximum concentrations of 1.7 and $1.5 \mathrm{mg} / \mathrm{L}$ respectively. Permissible levels of $\mathrm{Mn}^{2+}$ in drinking water according to the guidelines of TBS and WHO is $0.1-0.5$ and $0.05-0.5 \mathrm{mg} / \mathrm{L}$, respectively. The values obtained in this study are more than the permissible levels except for Majimoto borehole $\left(\mathrm{BHW}_{1}\right)$ water.

Groundwater tends to develop chemical characteristics that reflect the chemical composition of the water sources [23]. These are caused by water percolation through soil and rock and dissolve minerals containing $\mathrm{Fe}^{2+}$ and $\mathrm{Mn}^{2+}$ and hold them in solution. $\mathrm{Fe}^{2+}$ and $\mathrm{Mn}^{2+}$ in drinking water are not considered as hazardous to health. But high levels of $\mathrm{Fe}^{2+}$ in water can change the colour of water. High levels of $\mathrm{Mn}^{2+}$ can also turn water into black colour and it may cause people not to use it by expecting that the water is possibly contaminated. $\mathrm{Fe}^{2+}$ with the presence of $\mathrm{Mn}^{2+}$ in water may lead to the accumulation of microbial growth in the water distribution system [24]. The t-test $\left(\mathrm{p}=0.42>0.05\right.$ for $\mathrm{Fe}^{2+}$ and $\mathrm{p}=0.59>0.05$ for $\mathrm{Mn}^{2+}$ ) revealed that there is no significant difference of $\mathrm{Fe}^{2+}$ and $\mathrm{Mn}^{2+}$ between hot spring and borehole waters.

Table 3. Chemical parameters analysed by titrimetric methods.

\begin{tabular}{|c|c|c|c|c|c|c|c|c|c|c|c|c|}
\hline \multirow{3}{*}{ Samples } & \multicolumn{3}{|l|}{$\mathrm{Cl}^{-}$} & \multicolumn{3}{|c|}{ Total Hardness } & \multicolumn{3}{|l|}{$\mathrm{Ca}^{2+}$} & \multicolumn{3}{|l|}{$\mathrm{Mg}^{2+}$} \\
\hline & Mean & SD & $\%$ & Mean & SD & $\%$ & Mean & SD & $\%$ & Mean & SD & $\%$ \\
\hline & $(\mathrm{mg} / \mathrm{L})$ & $(n=3)$ & RSD & $(\mathrm{mg} / \mathrm{L})$ & $(n=3)$ & RSD & $(\mathrm{mg} / \mathrm{L})$ & $(n=3)$ & RSD & $(\mathrm{mg} / \mathrm{L})$ & $(n=3)$ & RSD \\
\hline $\mathrm{HSW}_{1}$ & 189.3 & 0.02 & 0.01 & 1.59 & 0.03 & 1.92 & 0.26 & 0.01 & 2.25 & 0.24 & 0.01 & 2.44 \\
\hline $\mathrm{HSW}_{2}$ & 674.26 & 0.05 & 0.01 & 7.2 & 0.1 & 1.39 & 1.9 & 0.02 & 1.05 & 0.58 & 0.02 & 3.45 \\
\hline $\mathrm{HSW}_{3}$ & 272.15 & 0.22 & 0.08 & 435.98 & 0.07 & 0.02 & 103.9 & 0.1 & 0.1 & 42.92 & 0.06 & 0.13 \\
\hline $\mathrm{HSW}_{4}$ & 3577.6 & 0.06 & 0 & 53.97 & 0.08 & 0.14 & 3.03 & 0.02 & 0.49 & 11.26 & 0.02 & 0.18 \\
\hline $\mathrm{BHW}_{1}$ & 6.25 & 0.01 & 0.16 & 22.08 & 0.02 & 0.07 & 7.01 & 0.02 & 0.22 & 1.11 & 0.03 & 2.7 \\
\hline $\mathrm{BHW}_{3}$ & 659.93 & 0.42 & 0.063 & 430.4 & 0.2 & 0.05 & 51.28 & 0.03 & 0.06 & 73.49 & 0.02 & 0.02 \\
\hline TBS & $200-800$ & & & $500-600$ & & & $50-100$ & & & $50-100$ & & \\
\hline WHO & $200-600$ & & & 300 & & & $150-200$ & & & $30-100$ & & \\
\hline
\end{tabular}

Table 4. Chemical parameters analysed by UV-Vis spectrophotometric methods.

\begin{tabular}{|c|c|c|c|c|c|c|c|c|c|c|c|c|c|c|c|}
\hline \multirow{3}{*}{ Samples } & \multicolumn{3}{|l|}{$\mathrm{NO}_{3}^{-}$} & \multicolumn{3}{|l|}{$\mathrm{SO}_{4}{ }^{2-}$} & \multicolumn{3}{|l|}{$\mathbf{F}^{-}$} & \multicolumn{3}{|l|}{$\mathrm{Fe}^{2+}$} & \multicolumn{3}{|l|}{$\mathrm{Mn}^{2+}$} \\
\hline & Mean & SD & $\%$ & Mean & SD & $\%$ & Mean & SD & $\%$ & Mean & SD & $\%$ & Mean & SD & $\%$ \\
\hline & $(\mathrm{mg} / \mathrm{L})$ & $(n=3)$ & RSD & $(\mathrm{mg} / \mathrm{L})$ & $(n=3)$ & RSD & $(\mathrm{mg} / \mathrm{L})$ & $(n=3)$ & RSD & $(\mathrm{mg} / \mathrm{L})$ & $(n=3)$ & RSD & $(\mathrm{mg} / \mathrm{L})$ & $(n=3)$ & RSD \\
\hline $\mathrm{HSW}_{1}$ & 0.02 & 0.02 & 125 & 447.59 & 1.09 & 0.24 & 10.50 & 0.50 & 4.76 & 0.003 & 0.01 & 173.20 & 2.00 & 0.10 & 5.00 \\
\hline $\mathrm{HSW}_{2}$ & 0.00 & 0.00 & 65.5 & 11.83 & 0.16 & 1.36 & 18.00 & 2.00 & 11.11 & 0.41 & 0.02 & 3.70 & 1.30 & 0.10 & 7.69 \\
\hline
\end{tabular}




\begin{tabular}{|c|c|c|c|c|c|c|c|c|c|c|c|c|c|c|c|}
\hline \multirow{3}{*}{ Samples } & \multicolumn{3}{|l|}{$\mathrm{NO}_{3}{ }^{-}$} & \multicolumn{3}{|l|}{$\mathrm{SO}_{4}{ }^{2-}$} & \multicolumn{3}{|l|}{$\mathrm{F}^{-}$} & \multicolumn{3}{|l|}{$\mathrm{Fe}^{2+}$} & \multicolumn{3}{|l|}{$\mathbf{M n}^{2+}$} \\
\hline & Mean & SD & $\%$ & Mean & SD & $\%$ & Mean & SD & $\%$ & Mean & SD & $\%$ & Mean & SD & $\%$ \\
\hline & $(\mathrm{mg} / \mathrm{L})$ & $(n=3)$ & RSD & $(\mathrm{mg} / \mathrm{L})$ & $(\mathrm{n}=3)$ & RSD & $(\mathrm{mg} / \mathrm{L})$ & $(\mathrm{n}=3)$ & RSD & $(\mathrm{mg} / \mathrm{L})$ & $(n=3)$ & RSD & $(\mathrm{mg} / \mathrm{L})$ & $(n=3)$ & RSD \\
\hline $\mathrm{HSW}_{3}$ & 2.81 & 0.25 & 8.94 & 571.00 & 30.05 & 5.26 & 4.68 & 0.02 & 0.43 & 0.02 & 0.02 & 65.47 & 1.50 & 0.10 & 6.67 \\
\hline $\mathrm{HSW}_{4}$ & 20.07 & 1.11 & 5.52 & 1353.30 & 94.52 & 6.98 & 9.30 & 0.13 & 1.35 & 0.07 & 0.01 & 14.29 & 1.03 & 0.15 & 14.78 \\
\hline $\mathrm{BHW}_{1}$ & 4.06 & 0.01 & 0.25 & 28.92 & 0.22 & 0.76 & 1.90 & 0.10 & 5.26 & 1.22 & 0.02 & 1.26 & 0.30 & 0.10 & 33.33 \\
\hline $\mathrm{BHW}_{2}$ & 18.57 & 0.25 & 1.36 & 367.54 & 0.55 & 0.15 & 3.00 & 0.10 & 3.33 & 0.28 & 0.02 & 7.52 & 1.70 & 0.10 & 5.88 \\
\hline $\mathrm{BHW}_{3}$ & 39.25 & 8.04 & 20.5 & 493.33 & 15.28 & 3.10 & 0.89 & 0.03 & 2.82 & 0.02 & 0.01 & 50.00 & 1.50 & 0.10 & 6.67 \\
\hline TBS & $10-75$ & & & $200-600$ & & & $1.5-4.0$ & & & $0.3-1.0$ & & & $0.1-0.5$ & & \\
\hline WHO & $45-50$ & & & $200-400$ & & & 1.5 & & & $0.1-1.0$ & & & $0.05-0.5$ & & \\
\hline
\end{tabular}

\subsection{Cadmium and Zinc}

Results showed that there are almost no or negligible concentrations of heavy metals $\mathrm{Cd}^{2+}$ and $\mathrm{Zn}^{2+}$ in both hot spring and borehole waters as observed in Table 5. It is observed that $\mathrm{Cd}^{2+}$ present only in hot spring waters. The concentration ranges from 0 to $0.05 \mathrm{mg} / \mathrm{L}$ with the highest value of $0.05 \mathrm{mg} / \mathrm{L}$ in Balangida Lalu hot springs $\left(\mathrm{HSW}_{4}\right)$, but the others contained the small concentrations of $\mathrm{Cd}^{2+}$ in hot springs and undetected levels of $\mathrm{Cd}^{2+}$ in borehole waters. Undetected levels are due to absence of any contamination with industrial or mining activities. The introduction of $\mathrm{Cd}^{2+}$ in water may originate from either geological formations or from other sources. The fact remains that the long term ingestion of water contaminated with cadmium may be hazardous to human health [25]. Higher concentrations of $\mathrm{Cd}^{2+}$ in hot springs indicate the presence of possible pollutant in water sources. Therefore, there is a need to educate society to maintain and established the habit of conserving hot spring as well as borehole waters. According to the TBS and WHO guidelines, the permissible levels of $\mathrm{Cd}^{2+}$ in drinking water are 0.05 and $0.003 \mathrm{mg} / \mathrm{L}$, respectively. Concentrations of $\mathrm{Cd}^{2+}$ above permissible levels can cause adverse changes in arteries of human kidneys [26]. The levels of cadmium obtained in the present study are less than the permissible levels. Hence, there will not be any health problems associated with the consumption of this water with respect to cadmium. The t-test indicates that there is no significant difference in $\mathrm{Cd}^{2+}$ concentration between hot springs and borehole waters with p-value $0.06>0.05$.

From Table 5, it is observed that there is no any concentration of $\mathrm{Zn}^{2+}$ in both hot spring and borehole waters except only two sites namely Masware $\left(\mathrm{HSW}_{3}\right)$ hot spring and Masware $\left(\mathrm{BHW}_{3}\right)$ borehole source with very low concentrations. The permissible levels of $\mathrm{Zn}^{2+}$ concentration in groundwater ranges from 0.01 to $0.05 \mathrm{mg} / \mathrm{L}$ according to WHO guidelines. The permissible levels according to guidelines of TBS range from 5 to $15 \mathrm{mg} / \mathrm{L}$. In this study the concentration of $\mathrm{Zn}^{2+}$ in the waters of all the sites less than the permissible levels. This may due to lack of geological materials with $\mathrm{Zn}^{2+}$ concentrations [27]. The p-values ( $\mathrm{p}=$ $0.44>0.05$ ) of t-test shows that there is no significant difference of $\mathrm{Zn}^{2+}$ between hot springs and borehole waters.

\subsection{Nickel}

Concentration ranges of $\mathrm{Ni}^{2+}$ are $0.63-0.83 \mathrm{mg} / \mathrm{L}$ in hot springs and $1.18-1.31 \mathrm{mg} / \mathrm{L}$ in borehole waters (Table 5).
Nickel can be present in some groundwater's as a consequence of dissolution from nickel ore-bearing rocks [28]. It's effect in humans is mostly due to chronic skin contact with nickel but women are more commonly allergic to nickel exposure than men [29]. But, when ingested through water, in small amounts, it is harmless to humans and in fact necessary in our diet [30]. Permissible levels of drinking water are $0.5 \mathrm{mg} / \mathrm{L}$ by TBS and $0.07 \mathrm{mg} / \mathrm{L}$ by WHO. The results of this study show that the $\mathrm{Ni}^{2+}$ concentrations in all the samples are above permissible levels. All the hot spring waters under this study have lower $\mathrm{Ni}^{2+}$ concentration than that of borehole waters due to the existence of soil nature. Hence, there is a need to treat the water for $\mathrm{Ni}^{2+}$ before consumption. The p-value obtained is $2.46 \times 10^{-4}<$ 0.05 from t-test which indicates that there is significant difference in nickel concentrations between hot springs and borehole waters.

\subsection{Copper}

From the Table 5 it is observed that the concentration of $\mathrm{Cu}^{2+}$ is highest in Balangida Lalu $\left(\mathrm{HSW}_{4}\right)$ and Masware $\left(\mathrm{HSW}_{3}\right)$ hot springs with concentrations 0.93 and $0.91 \mathrm{mg} / \mathrm{L}$ and these values are higher than that of any of borehole waters under the study. Intake of drinking water that contaminated with $\mathrm{Cu}^{2+}$ concentration greater than $3 \mathrm{mg} / \mathrm{L}$ in adult causes gastrointestinal effect and elicited nausea. The human body has a natural mechanism for maintaining the proper level of $\mathrm{Cu}^{2+}$ in it. Children below one year old have not yet developed this mechanism as a result these are more vulnerable to the toxic effects of copper [31]. Values of $\mathrm{Cu}^{2+}$ obtained in this study are below permissible levels set by TBS which ranges from 1 to $3 \mathrm{mg} / \mathrm{L}$ and for WHO 0.005 to 2 $\mathrm{mg} / \mathrm{L}$. Small amounts of $\mathrm{Cu}^{2+}$ are essential for good health but excess of $\mathrm{Cu}^{2+}$ can cause anemia and liver, kidney and brain damage. The $\mathrm{p}$-value of t-test is $0.66>0.05$ indicated that there is no significant difference of $\mathrm{Cu}^{2+}$ between hot springs and borehole waters.

\subsection{Potassium}

Highest concentration of $\mathrm{K}^{+}$observed in Balangida Lalu $\left(\mathrm{HSW}_{4}\right)$ hot spring with $100 \mathrm{mg} / \mathrm{L}$ (Table 5). Among the borehole waters, the highest was present in Masware $\left(\mathrm{BHW}_{3}\right)$ borehole water with $52 \mathrm{mg} / \mathrm{L}$ as shown in Table 5. This is due to presence of $\mathrm{K}^{+}$ions in groundwater which indicate the existence of many rocks in study sites with $\mathrm{K}^{+}$salts. In general, the concentrations of $\mathrm{K}^{+}$in hot springs greater than that of borehole waters. Lowest concentration of $\mathrm{K}^{+}$is 
present in Usangore $\left(\mathrm{HSW}_{2}\right)$ hot springs and Majimoto $\left(\mathrm{BHW}_{1}\right)$ borehole waters with their concentrations of 44 and $16 \mathrm{mg} / \mathrm{L}$ respectively. The sources of $\mathrm{K}^{+}$is likely due to silicate minerals, orthoclase, microcline, hornblende, muscovite and biotite in igneous and metamorphic rocks [32]. Nature of rocks dictates $\mathrm{K}^{+}$concentration in hot springs and borehole waters. Potassium is an essential element in humans and seldom found in drinking water. But at higher levels it will cause certain health problems to humans. The permissible levels of drinking water not well stated by TBS and WHO but only shows its importance for the playing a critical role in many vital cell functions, such as metabolism, growth, repair and regulation, as well as in the electric properties of the cell. Therefore $\mathrm{K}^{+}$works with sodium to maintain the body's water balance and is also involved in nerve function, muscle control and blood pressure. There is no significant difference of $\mathrm{K}^{+}$between hot springs and borehole waters from t-test with a p-value of $0.08>0.05$.

Table 5. Chemical parameters analysed by Flame Atomic Absorption Spectrometric methods.

\begin{tabular}{|c|c|c|c|c|c|c|c|c|c|c|c|c|c|c|c|}
\hline \multirow{3}{*}{ Samples } & \multicolumn{3}{|l|}{$\mathbf{C d}^{2+}$} & \multicolumn{3}{|l|}{$\mathrm{Zn}^{2+}$} & \multicolumn{3}{|l|}{$\mathrm{Ni}^{2+}$} & \multicolumn{3}{|l|}{$\mathrm{Cu}^{2+}$} & \multicolumn{3}{|l|}{$\mathbf{K}^{+}$} \\
\hline & Mean & SD & $\%$ & Mean & SD & $\%$ & Mean & SD & $\%$ & Mean & SD & $\%$ & Mean & SD & $\%$ \\
\hline & $(\mathrm{mg} / \mathrm{L})$ & $(n=3)$ & RSD & $(\mathrm{mg} / \mathrm{L})$ & $(n=3)$ & RSD & $(\mathrm{mg} / \mathrm{L})$ & $(n=3)$ & RSD & $(\mathrm{mg} / \mathrm{L})$ & $(n=3)$ & RSD & $(\mathrm{mg} / \mathrm{L})$ & $(n=3)$ & RSD \\
\hline $\mathrm{HSW}_{1}$ & 0.02 & 0.01 & 34.64 & 0.00 & 0.00 & 0.00 & 0.63 & 0.01 & 1.59 & 0.4 & 0.01 & 2.5 & 56.00 & 2.00 & 3.57 \\
\hline $\mathrm{HSW}_{3}$ & 0.01 & 0.01 & 100.00 & 0.05 & 0.01 & 20.00 & 0.69 & 0.01 & 1.45 & 0.91 & 0.01 & 1.1 & 64.00 & 2.00 & 3.13 \\
\hline $\mathrm{HSW}_{4}$ & 0.05 & 0.01 & 20.00 & 0.00 & 0.00 & 0.00 & 0.83 & 0.01 & 1.21 & 0.93 & 0.02 & 2.15 & 100.00 & 1.00 & 1.00 \\
\hline $\mathrm{BHW}_{1}$ & 0.00 & 0.00 & 0.00 & 0.00 & 0.00 & 0.00 & 1.18 & 0.01 & 0.85 & 0.49 & 0.01 & 2.04 & 16.00 & 1.00 & 6.25 \\
\hline $\mathrm{BHW}_{3}$ & 0.00 & 0.00 & 0.00 & 0.94 & 0.01 & 1.06 & 1.31 & 0.01 & 0.76 & 0.64 & 0.02 & 3.13 & 52.00 & 2.00 & 3.85 \\
\hline TBS & 0.05 & & & $5-15$ & & & 0.5 & & & 1 to 3 & & & NLS & & \\
\hline WHO & 0.003 & & & $0.01-0$. & & & 0.07 & & & $0.005-2$ & & & NLS & & \\
\hline
\end{tabular}

NLS* No Limit Specified.

\section{Conclusion}

In this study, water quality of hot springs and borehole waters tested and compared by collecting water samples from seven different locations selected in northern Tanzania. Selected physico-chemical parameters are $\mathrm{pH}$, EC, TDS, salinity, turbidity, $\mathrm{Cl}^{-}$, total hardness, $\mathrm{Ca}^{2+}$, $\mathrm{Mg}^{2+}, \mathrm{NO}_{3}^{-}, \mathrm{SO}_{4}{ }^{2-}, \mathrm{F}^{-}, \mathrm{Fe}^{2+}, \mathrm{Mn}^{2+}, \mathrm{Cd}^{2+}, \mathrm{Zn}^{2+}, \mathrm{Ni}^{2+}, \mathrm{Cu}^{2+}$ and $\mathrm{K}^{+}$analyzed to predict the water quality status of hot spring and borehole waters of three regions (Mara, Shinyanga and Manyara) in Tanzania. The EC, TDS, salinity, turbidity, $\mathrm{Cl}^{-}, \mathrm{NO}_{3}{ }^{-}, \mathrm{SO}_{4}{ }^{2-}, \mathrm{F}^{-}, \mathrm{Mn}^{2+}$ and $\mathrm{Cu}^{2+}$ are higher $(\mathrm{pH}=7.44-9.42, \mathrm{EC}=4251.33-15334 \mu \mathrm{S} / \mathrm{cm}$, TDS $=2079-7526.7 \mathrm{mg} / \mathrm{L}$, salinity $=2.2-8.67 \mathrm{ppt}, \mathrm{Cl}^{-}=189.3-$ $3577.6 \mathrm{mg} / \mathrm{L}, \mathrm{SO}_{4}{ }^{2-}=11.83-1353.33 \mathrm{mg} / \mathrm{L}, \mathrm{F}^{-}=4.68-18$ $\mathrm{mg} / \mathrm{L}, \mathrm{Mn}^{2+}=1.03-2.0 \mathrm{mg} / \mathrm{L}, \mathrm{Cd}^{2+}=0.01-0.05 \mathrm{mg} / \mathrm{L}, \mathrm{Cu}^{2+}$ $=0.37-0.93 \mathrm{mg} / \mathrm{L}$ and $\mathrm{K}^{+}=44-100 \mathrm{mg} / \mathrm{L}$ ) in hot springs than borehole waters $(\mathrm{pH}=6.36-6.58, \mathrm{EC}=270.0$ $2674.64 \mu \mathrm{S} / \mathrm{cm}$, TDS $=123.67-1305 \mathrm{mg} / \mathrm{L}$, salinity $=$ 0.03-1.37 ppt, $\mathrm{Cl}^{-}=6.25-659.93 \mathrm{mg} / \mathrm{L}, \mathrm{SO}_{4}{ }^{2-}=28.92-$ $493.33 \mathrm{mg} / \mathrm{L}, \mathrm{F}^{-}=0.89-3.0 \mathrm{mg} / \mathrm{L}, \mathrm{Mn}^{2+}=0.3-1.70 \mathrm{mg} / \mathrm{L}$ $\mathrm{Cd}^{2+}=0 \mathrm{mg} / \mathrm{L}, \mathrm{Cu}^{2+}=0.49-0.64 \mathrm{mg} / \mathrm{L}$ and $\mathrm{K}^{+}=16-52$ $\mathrm{mg} / \mathrm{L}$ ). From the t-test on individual parameters, there is no significant difference between the quality of hot spring water and borehole waters except for $\mathrm{pH}$ and $\mathrm{Ni}^{2+}$. Based on this study it can be concluded that there is a need for treatment of both waters with reference to certain physicochemical parameters before drinking. Moreover, additional measures must be taken by the Tanzania government and stake holders to improve the water quality of rural areas near hot spring sources in Tanzania in order to supply clean and safe water to the communities as well as to solve the water scarcity problems.

\section{References}

[1] Okoro, N., Omeje, E. O., and Osadebe, P. O. Comparative analysis of three borehole water sources in Nsukka urban area, Enugu state, Nigeria, Resour. and Environ, 2017, 7 (4): 110-114.

[2] Futakamba, M., Water Sector Development Programme, Status report, Dar es salaam: Tanzania, 2016.

[3] Rubhera, R. A. M. M., Groundwater quality degradation due to salt water intrusion in Zanzibar municipality, African J. Environ. Sci. Technol., 2014, 9 (9): 734-740.

[4] Jana, O., and Jonker, N., Optimal utilisation of thermal springs, Water Research Commission, Gezina, South Africa, WRC Report No. TT 577/13, 2013.

[5] Kifua, G., Reconnaissance of geothermal resources, Dar es salaam, Tanzania, 1958.

[6] Mnzava, L. J., and Mayo, A. W., Geochemical investigation of geothermal power potential exploration of hot springs in South-western Tanzania, Int. J. Water Resour. and Environ. Eng., 2013, 5 (10): 597-607.

[7] Nancy, J. M. M., Water supply in Tanzania and performance of local plant materials in purification of turbid water, $\mathrm{Ph}$. D. Thesis, Royal Institute of Technology, Stockholm, Sweden, 2008.

[8] Chaurasia, N., Pandey, S. K., and Devendra, M., Determination of arsenic content in the water and blood samples of Ballia region using hydride generation atomic absorption spectrophotometer, Res. J. Forensic Sci., 2013, 1 (4): $1-3$

[9] Kamil, E., Gwen, H., David, B., and Walter, B., Thermal characteristics of the Chena hot springs Alaska geothermal system," in Thirty-Second Workshop on Geothermal Reservoir Engineering, Stanford University, California, 2007, 1-8. 
[10] Toure, A., Wenbiao, D., and Keita, Z., Comparative study of the physico-chemical quality of water from wells, boreholes and rivers consumed in the commune of pelengana of the region of Segou in Mali, Environ. Sci., 2017, 13 (6): 1-13.

[11] Alhibshi, E., Albriky, K., and Bushita, A., Concentration of heavy metals in underground water wells in Gharian district, Libya, Int. Conf. Agric. Ecol. Med. Sci., Indonesia, 2014, 3539.

[12] Korkmaz, N., and Gunduz, M., and Asik, S., Temporal and spatial variation of groundwater level and salinity: A case study in the irrigated area of Menemen plain in western Turkey, Hungarian Agric. Eng., 2015, DOI: 10.17676/HAE.2015.28.39, 39-43.

[13] Sayyed, J. A., and Bhosle, A. B., Analysis of chloride, sodium and potassium in groundwater samples of Nanded city in Mahabharata, India, Euro. J. Exp. Bio., 2011, 1 (1): 74-82.

[14] Heston, D., Total carbonate hardness in Cumberland valley groundwater, M. Sc. Thesis, A Shippensburg University, 2015, USA, $1-22$

[15] Hollocher, T. C., and Kristjansson, J. K., Thermophilic denitrifying bacteria: A survey of hot springs in South-western Iceland, FEMS Microbiol. Lett., 1992, 101 (2): 113-119.

[16] Tiwari, P., Water quality assesment for drinking and irrigation purpose, Indian J. Sci. Res., 2017, 13 (2): 140-142.

[17] Prakash, P., Gupta, B. K., and Ahmad, M. F., Characteristics of hot water springs in a region of Rishikund Munger district of Bihar State, India, Int. Res. J. Environ. Sci., 2017, 6 (10): $15-21$.

[18] Hodder, P. W., Geothermal Waters as a source of energy and metals, University of Waikato: New Zealand, 2010.

[19] Mohammad, A. Z., Reza, S., and Laleh, R. K., Calculating fluoride concentrations data using ambient temperatures in drinking water distribution networks in select provinces of Iran, Data in Brief, 2017, 12: 127-132.

[20] Berhanu, G., Excessive fluoride concentration in the Ethiopian rift and the flowered project, 2017, EU H2020 Project, 1-53.

[21] Gautam, R., and Bhardwaj, N., Fluoride accumulation in milk samples of domestic animals of Nawa Tehsil in Nagaur district (Rajasthan), The Ecoscan, 2009, 3 (3 \& 4): 325-326.
[22] Battaleb, L. S., Moore, S., A study of fluoride groundwater occurrence in Posht-e-Kooh-e-Dashtestan, South of Iran, World Appl. Sci. J., 2010, 8 (11): 1317-1321.

[23] Choubisa, S. L., Mishra, G. V., Zulfiya, S., Bhardwaj, B., Mali, p., and Jaroli, V. J., Food, fluoride and fluorosis in domestic ruminants in the Dungarpur district of Rajasthan, India, Research Report Fluoride, 2011, 44 (2): 70-76.

[24] Bruce, I. D., Drinking water: Iron and Manganese, Nebguide., University of Nebraska-Lincoln, USA, 2014, 1-4.

[25] Baytak, S., Turker, A. R., Determination of chromium, cadmium and manganese in water and fish samples after preconcentration using penicillium digitatum immobilized on Pumice stone, clean, 2009, 37 (4-5): 314-318.

[26] Festo, H., Ngowi, A. V., Ohanianr, E. Y., and Magara, E., Cadmium in drinking water, WHO Guideline Drink. Water Qual., 2011, 3 (4): 60-116.

[27] Dutta, D., and Sarma, H. P., Copper (Cu), Zinc (Zn) and Cadmium $(\mathrm{Cd})$ contamination of groundwater in Dikrong river basin, Paumpare district, Arunachal Pradesh, India, IOSR J. Environ. Sci. Toxicol. and Food Technol., 2015, 9 (10): 20-23.

[28] Srikanth, R., Rao, A. M., Kumar, Ch. S., and Khanum, A., Lead, cadmium, nickel, and zinc contamination of groundwater around Hussain sagar lake, Hyderabad, India, Bull. Environ. Contam. and Toxicol., 1993, 50 (1): 138-143.

[29] Fernanda, T., Maria das, G., Mota, M., and Antonelle, T., Management of contact determatitis due to nickel allergy: An update, Clin. Cosmet. Investig. Dermatology., 2009, 2: 39-48.

[30] Cotruvo, J., Giddings, E., Jackson, P., Magara, Y., and Ohanian, Y., Nickel in drinking water, WHO guidelines for Drinking Water Quality, 2005, 1-29.

[31] Toft, P., Magara, Y., and Jackson, P., Copper in drinking water. WHO guidelines for drinking water quality, 2004, 1-31.

[32] Aiwerasia, V. F. N., Ohanian, E., Potassium in drinking water, WHO guidelines for drinking water quality, 2009, 1-12. 